\title{
Conflict-induced displacement as a catalyst for agricultural innovation: findings from South Sudan
}

Article

Accepted Version

Creative Commons: Attribution-Noncommercial-No Derivative Works 4.0

Leonardo, E., Dorward, P., Garforth, C., Sutcliffe, C. and Van Hulst, F. (2020) Conflict-induced displacement as a catalyst for agricultural innovation: findings from South Sudan. Land Use Policy, 90. 104272. ISSN 0264-8377 doi:

https://doi.org/10.1016/j.landusepol.2019.104272 Available at https://centaur.reading.ac.uk/86113/

It is advisable to refer to the publisher's version if you intend to cite from the work. See Guidance on citing.

To link to this article DOI: http://dx.doi.org/10.1016/j.landusepol.2019.104272

Publisher: Elsevier

All outputs in CentAUR are protected by Intellectual Property Rights law, including copyright law. Copyright and IPR is retained by the creators or other copyright holders. Terms and conditions for use of this material are defined in the End User Agreement.

www.reading.ac.uk/centaur 
Central Archive at the University of Reading

Reading's research outputs online 


\title{
Conflict-induced displacement as a catalyst for agricultural innovation: findings from South Sudan
}

\author{
Elias Leonardo $^{\text {a1 }}$, Peter Dorward ${ }^{\mathrm{a}}$, Chris Garforth $^{\mathrm{a}}$, Chloe Sutcliffe ${ }^{\mathrm{a} 2}$ \\ Freddy Van Hulst ${ }^{\mathrm{a} *}$
}

${ }^{a}$ School of Agriculture, Policy and Development, University of Reading, Reading, United Kingdom; ${ }^{b}$ Department, University, City, Country

*Correspondence details: f.vanhulst@ reading.ac.uk, School of Agriculture, Policy and Development, University of Reading, Whiteknights campus, PO Box 237, Reading, RG6 6AR, United Kingdom.

Accepted by Land Use Policy 10 Oct 2019

\footnotetext{
${ }^{1}$ Now working at the Permanent Secretariat of the Northern Corridor Transit and Transport Coordination Authority, Mombasa, Kenya

${ }^{2}$ Now working at School of Water, Energy and Environment, Cranfield University, Cranfield, UK 


\begin{abstract}
This article explores how conflict-induced displacement influences agricultural innovation processes and systems, and its implications after the return home or permanent resettlement of smallholder farmers. Results show that high rates of agricultural innovation occurred during displacement in the Sudanese Civil War (1983-2005), many of which were maintained afterwards. Respondents cited the need for adaptation to new social and physical circumstances, changed gender roles, and enhanced inter-household communication as contributing to increased opportunities for knowledge exchange, trade, and importantly, the development of new networks, modes of organisation and social norms. Furthermore, returnees to South Sudan have embodied these changes together with new values, habits and expectations. New linkages continued across borders between returnees and non-returnees, facilitating knowledge exchange and access to resources, markets and sources of ideas. A high degree of autonomous innovation capacity was also evident. Further research is required on the dynamics and processes associated with innovation in conflictinduced displacement. It is important for policy makers to encourage approaches that seek to actively tap into and build on the institutional, human and social capital built during displacement.
\end{abstract}

\title{
1. INTRODUCTION
}

Current levels of global population displacement resulting from conflict exceed records since measurements began (UNHCR, 2018). By the end of 2017, a staggering 68.5 million individuals had been forcibly displaced across the globe, with this number continuing to rise (UNHCR, 2018). Violent conflicts and instability in parts of sub-Sahara Africa (SSA) have had a profound impact on the performance and progress of the agriculture sector (Straus, 2012). Following conflicts, agriculture sectors can be severely weakened, with national agricultural support systems including research, education and extension immobilised, and crucial logistical infrastructure destroyed or damaged (Muscat, 2005). The impacts of conflict on agricultural development are particularly salient in countries situated in the global south, where agriculture makes up a substantial part of the national economy. 
Sixty-five percent of all the states in SSA have experienced conflict since independence, and since the year 2000 there have been on average between eight and ten conflicts on the continent in any given year (Straus, 2012). Besides direct loss of livelihood assets and disruption to livelihood activities, these conflicts also result in forced migration of populations as refugee (often to a neighbouring country) or as internally displaced person (IDP). It is estimated that at the end of 2016, SSA had over 5.1 million refugees (UNHCR, 2017), with the number of IDPs adding a further 13.4 million (IDMC and Norwegian Refugee Council, 2018). While SSA accounts for only 15 per cent of the global population, the number of new IDPs in SSA in 2017 accounts for almost half of the global figure with 5.5 million, including 857,000 new IDPs in South Sudan (ibid). In 2018, the total number of refugees and IDPs in South Sudan estimated to be close to 2,5 million people, of whom more than 1 million are displaced in Uganda, 0,7 million in Sudan and 0,4 million in Ethiopia ${ }^{3}$. Of the many countries in SSA that have suffered conflict and population displacement, South Sudan is amongst the most severely affected.

In South Sudan and Sudan, opposing forces have been actively fighting for many decades, peaking in two civil wars between 1955-1972 and 1983-2005. In 2005, when the Comprehensive Peace Agreement was signed by the Sudanese Government and the Sudan People's Liberation Army/Movement (SPLA/M), violence declined dramatically (Daoust, 2015). However, since this time conflict has again increased. Despite secession in $2011^{4}$, levels of violent conflict have continued to rise in recent years, with heavy fighting erupting in South Sudan in December 2013. Violence against civilians continues to be extremely high, with the United Nations High Commissioner for Refugees (UNHCR) identifying both South Sudan and Sudan as two of the most significant humanitarian crises of 2014 (Daoust, 2015). In August 2015 the conflicting parties signed a peace agreement, but fighting has continued since.

${ }^{3}$ UNHCR fact sheet South Sudan: https://data2.unhcr.org/en/situations/southsudan (accessed 10-2018).

4 This article reports research carried out prior to secession in 2011 in a region that became part of South Sudan. For continuity's sake, the rest of the text will refer to the area as part of South Sudan. 
The Second Sudanese Civil War displaced much of the population in South Sudan. Although a large number of people had returned to their homes by December 2011, available figures show that there were still 2.2 million IDPs in Sudan and an estimated 373,000 refugees registered by UNHCR (Ferris, 2012). The violence of South Sudan's past and present is considered to set the country's development back by many years, with maternal mortality rates amongst the highest in the world, high levels of illiteracy and increasing food insecurity (UNDP, 2015). Questions about how best to support development for populations affected by violent conflict and displacement are therefore of paramount concern in South Sudan and in similar contexts affected by violent conflict and forced migration.

Much writing concerning violent conflict in Africa rightfully concentrates on its political causes and human costs (Buhaug and Rød, 2006; Østby et al., 2009). However, the forced breakdown of institutional and social norms that occurs during periods of upheaval and displacement also provides space for the development of new ways of organising livelihoods, as recognised in the literature on natural disaster responses (Birkmann et al., 2010; Tran, 2015). In agricultural systems, traditional prevailing social structures that determine access to land, labour, and financial and social capital are likely to be altered in some way by conflicts (Cramer and Richards, 2011; Vervisch et al., 2013). It is increasingly recognised that agricultural innovation and natural resources management play an important role in peacebuilding in the wake of armed conflict (Bruch and Muffett, 2016; Hellin et al., 2018).

This article reports research undertaken with smallholder farmers in South Sudan affected by the Second Sudanese Civil War. Without in any way downplaying the hardships and challenges that result from conflict and displacement, this article explores how encountering new experiences and sources of knowledge in refugee and IDP camps may contribute to processes of agricultural innovation and an improved innovation capacity of smallholder farmers after the return home or permanent resettlement. The objectives are to identify the agricultural innovations that occurred during displacement and conflict and identify the sources of support for these innovations. By exploring participants' perceptions of the factors that contributed to the innovation process we arrive at conclusions that can inform future policy and interventions aiming at enhancing support for agricultural innovation amongst those affected or displaced by conflict. 


\section{POST-CONFLICT AGRICULTURAL INNOVATION}

The questions of where, how and why agricultural innovation occurs has been answered differently in the past decades. The successive development of theories of innovation have influenced strategies for supporting agricultural development. For the purposes of this article we distinguish between the linear 'diffusion of innovations' model (for example Rogers, 2003), and an Agricultural Innovation Systems approach (for example Hall et al., 2007). The linear model, where innovations are channelled down communication chains through social hierarchies, has been highly influential in determining the delivery of agricultural extension services throughout the world (Röling and Pretty, 1997). However, it has been criticised for treating adopters as passive recipients of innovations and for utilising an overly simplistic, uni-directional, linear conceptualisation of communications (Engel and van den Bor, 1995; German et al., 2006). Several authors have questioned its application to developing country scenarios due to its pro-modernisation bias (Agarwal, 1983), with some arguing that its approach can widen inequalities (Roberts, 1989; Röling et al., 2004).

Post-conflict agricultural programmes have frequently focussed on the provision of tangible inputs such as seeds and tools, and in some cases credit (Sperling, 2002). However, the provision of this kind of support can have unintended negative consequences, for example by reducing cultivar diversity and destabilising social relations and local markets (Sperling, 2002). Other problems may include successfully targeting provisions to the most needy, the danger of stunting the recovery of agricultural inputs markets, the introduction of social discord (where inputs are not universally provided), the loss of agricultural diversity through the rushed provision of poorly suited cultivars, issues of aid dependency, and the danger of high rates of credit default (Muscat, 2005). In South Sudan, land tenure and highly contested governance of communal and private land is also recognised as a crucial factor affecting opportunities for agricultural development after return from displacement (Hirblinger, 2015; Van Leeuwen et al., 2018).

While provision of tangible assets for post-conflict agricultural support has a legitimate place, it can reinforce traditional understandings of agricultural innovation diffusion, where innovations are channelled down linear social hierarchies (Rogers, 2003). Meanwhile, the resourcefulness and conscientiousness of refugee populations is often noted by commentators, as is their potential to innovate and succeed economically in new situations (Airriess, 2005; Vemuru et al., 2016). This suggests 
that greater support is warranted for autonomous efforts by refugees and IDPs to rebuild their livelihoods (Sperling, 2002).

Indeed, current thinking about agricultural innovation places greater emphasis on the diversity of actors involved in innovation, and their contribution to creating and sharing knowledge, as evident in the Agricultural Knowledge and Information Systems (AKIS) approach (Roling and Engel, 1991) and then the Agricultural Innovation Systems (AIS) approach (Hall et al., 2007; Moris, 1991; World Bank, 2012). AIS presents a model of innovation as the product of multi-directional knowledge transfer and co-learning between a web or network of organisations and individuals (Mekonnen et al., 2015). Operating at a systems level, AIS thinking can be used to evaluate institutional support for agricultural innovation, directing scrutiny to the functioning of the knowledge and education and business domains and the bridging institutions which facilitate knowledge transfer between them (Mekonnen et al., 2015; Spielman and Birner, 2008).

An AIS approach strongly emphasises the overarching importance of social capital, institutions and knowledge-sharing in multi-directional networks and may guide considerably different modes of post-conflict support for agricultural reconstruction and development. It encourages a focus on soft systems approaches that facilitate interaction between individuals and groups (Klerkx et al., 2012) with a greater focus on delivering and facilitating the production, adaptation and transfer of knowledge rather than the delivery of tangible technologies (Agwu et al., 2008). For some authors, the AIS approach has provided a recognition of innovation as a 'collective process' that requires 'space for change' across multiple socio-institutional (legal, cultural, relational, economic and political) and bio-physical (technical, geographical, ecological and temporal) dimensions (Leeuwis and Aarts, 2011: 27).

Violent conflicts and displacement tend to impact many aspects of the socioinstitutional and bio-physical spaces that affected populations inhabit, and as such will impact the scope for innovation. What this article aims to explore is whether and how forced migration and spending time in refugee or IDP camps can contribute to new spaces of opportunity for livelihoods and agricultural innovation.

\section{METHODS}

To understand the occurrence and incidence of support for agricultural innovations during and after violent conflicts, research was conducted in the Eastern 
and Central states of the Equatoria region of South Sudan, which suffered from a long period of violent conflict spanning more than two decades (1983-2005). The

Equatoria region was selected because more agricultural activities are conducted there than in the other two regions of Upper Nile and Bahr el Ghazal. The region also borders five countries (Ethiopia, Kenya, Uganda, Democratic Republic of Congo and Central African Republic) increasing the breadth of the new contact networks and experiences that displaced farmers could potentially be exposed to.

The study combined a range of data collection methods including 10 key informant interviews, 13 focus group discussions (FGDs) and a household survey $(n=156)$. At the beginning of the research, ten key informant farmers were identified from across the Equatoria region based on their knowledge of the area and the issues under study. Discussions with these informants guided the final selection of research sites and participants. The 13 FGDs were conducted across the five counties of the Equatoria region each with 5 to 11 participants. FGD groups were carefully selected with the help of local authorities and key informants and each FGD included smallholder farmers who had been displaced internationally, nationally and who had never left. In total, 102 farmers participated in these discussions, which focussed on identifying agricultural innovations perceived to have occurred during and after the conflict period and the question of how participants' agricultural activities were supported during this period.

Preliminary analysis of the information from key informant interviews and the FGDs was conducted based on emerging themes and then used in the formulation of the household survey questionnaire. The household survey was used to supplement and triangulate qualitative data as well as to capture demographic characteristics of the different categories of respondents. Households were purposively selected based on the nature of displacement experienced during the conflict. Nearly all the respondents encountered had been displaced to either neighbouring countries or to other locations inside South Sudan: Just 5 non-displaced farmers were identified that were willing to participate in the survey. 110 farmers who had been internally displaced within South Sudan completed the survey, as did 41 individuals who had been displaced to neighbouring countries. In total, 156 farmers took part in the survey questionnaire. All fieldwork took place in 2009. The quantitative data was coded manually and then analysed using SPSS version 17. 


\section{RESULTS}

\subsection{Reported agricultural innovations in South Sudan}

Research participants reported that many innovations had been incorporated into agricultural practice following the period of conflict and attributed these to the new experiences and information sources that populations encountered whilst displaced. An overview of agricultural innovations identified during the FGDs is given in Table 1, which also shows the sources of these innovations and the actors that supported them during the conflict and the country of origin.

[Table 1 near here]

Indeed, many new practices have been incorporated into farming activities following the conflict, including the adoption of new crops, crop varieties and types of livestock, and new processing techniques, but also changes to gender roles and an increasing focus on agricultural production for commerce. Overall, FGD participants reported that the highest rates of innovation occurred amongst households that went to refugee camps in other countries, with internally-displaced households coming second, and non-displaced households displaying the lowest rates.

The household survey data confirmed the interesting finding that that postconflict gender relations had changed. Post-conflict involvement in livestock sales was almost evenly divided between men and women, with women constituting 44 per cent of those engaged in sales $(n=95)$. This differed markedly to the situation before the conflict, when livestock sales were considered a male domain. The household survey further showed that main livelihood activities before and after the conflict differed significantly. After the conflict, households were much more engaged in diversified activities including off-farm employment, trade and services.

\subsection{Sources of agricultural extension and livelihood support}

\subsubsection{Sources of agricultural information and ideas}

The five main sources of information regarding agricultural innovations were identified by FGD participant as follows: relatives and friends, NGO and government extension networks, other farmers and the media. Participants were asked to indicate how frequently they accessed information from each of these sources by allocating a number between 1 (almost never) and 5 (always). Across the 13 FGDs, relatives and friends consistently featured as the most frequently accessed information source, 
whilst information coming from government extension was least frequently accessed (see Table 2).

In explaining the rankings, FGD participants emphasised that knowledgesharing and innovation support is most effective between households because of the trust that exists between friends, relatives and neighbours. Participants emphasised that farmers tended to be sceptical of information obtained from outside sources, but indicated that information received through other farmers within their own or neighbouring villages, particularly information coming from individuals that are perceived to be innovative, is taken up readily. Media was the information source that participants accessed the second most frequently on average. Participants particularly mentioned the use of FM radios as sources of agricultural information. This is possibly also linked to the issue of trust, since many farming stations featured farmers explaining their innovative practices. Whilst only half of FGD participants owned radios themselves, all indicated that demand for radios had grown post-conflict and radio ownership was something to which all households now aspired.

[Table 2 near here]

Research participants were asked to compare access to agricultural information from these sources during and after the conflict. Their responses indicated that access to all sources of agricultural information declined in the postconflict period. This was explained with the narrative that returning populations once more adopted their traditional, widely-dispersed dwelling patterns, reducing interhousehold communication levels compared to those during relocation, and thus negatively impacting abilities to gain access to sources of information about agriculture.

\subsubsection{Sources of agricultural support}

The experience of being displaced had increased access to support that enabled agricultural innovation for many of the respondents. For example, some FGD participants stated that the conflict and displacement had exposed them to credit opportunities. Participants also noted, however, that only a very small minority of farmers had benefited from credit provision. More widely, for those that were displaced to neighbouring countries, there were opportunities to benefit from active 
social and agricultural development programmes, and refugees were noted particularly to have benefitted from initiatives that were intended to boost agricultural development in Uganda. The civil war was also considered to have opened up education opportunities for inhabitants of South Sudan, by lifting previous political and economic barriers to obtaining education.

Earlier we observed that innovations were predominantly seen to originate from countries neighbouring South Sudan, with NGOs featuring prominently alongside individuals as the main sources of support for these innovations (Table 1 and 2). As such, NGOs seem to be important bridging institutions that help facilitate support for innovation in the quickly evolving actor networks in a migration context, which is an important function in innovation systems (Spielman and Birner, 2008). However, focus group participants did not list NGOs as important providers of support for agricultural innovation. Indeed, households were unanimously identified by FGD participants as sources of support for agricultural innovations, while support also came in the form of credit, extension services and markets (each mentioned by 5 of the 13 groups). After NGOs (mentioned in only three FGDs), government policies featured the least of all, only gaining mention at two of the groups.

The consistent finding of the high importance given to relatives, friends and other households in terms of support for agricultural innovation suggests that while NGOs appear to have played an important role in introducing new ideas that influenced innovation amongst displaced households, for the majority, support for innovation was received from immediate social networks.

\subsubsection{Sources of livelihood support}

Participants were asked to rank access to a range of services for livelihood support for those in refugee camps, those that were displaced internally, and those that never moved from their home locations (see Table 3). These support services consisted of education, health, technology, markets, NGOs, extension, credit and relief food services. FGD participants awarded access to each support service a score between 1 (unacceptable access) and 5 (excellent access). There was strong agreement amongst all FGDs that access to support services was stronger in settlements for IDPs and refugees than in the areas from which participants had been displaced. Overall, participants reported the best access to services in refugee camps (median $=3$ ), with IDP locations coming second (median $=2$ ) and access to support services in home 
locations mostly considered unacceptable (median $=1)$. These differences were all significant (pair-wise Mann-Whitney test, $\mathrm{p}<0.05$ ). Access to NGOs, education, health services and markets were considered much better in displaced locations.

[Table 3 near here]

\subsection{How displacement can contribute to innovation}

Participants reported having lost access to resources during displacement: the majority moved when their villages were attacked and only took with them what they could carry, meaning they brought little in the way of material support for livelihood activities to their new locations. Arriving in new locations with next to nothing, FGD participants stated that they had to accept and adopt whatever means of providing a livelihood were available to them. As such, they could not take time to evaluate the qualities of agricultural innovations before deciding whether to adopt them (contrary to the conventional adoption models that include an awareness and decision-making phase, see for example Prager and Posthumus (2010)). Participants felt that this greatly increased the rate at which innovation occurred, in addition to a more networked mode of innovation compared with the more linear mode of innovation diffusion that was perceived to have dominated prior to the conflict.

In addition, participants reported that they were in the position of needing to adapt their agricultural practices to new production conditions and constraints. Land sizes available to households in camps were considerably smaller than in their home locations, and this, in addition to the loss of livestock assets during the conflict, led to increasing participation in crop production, the abandonment of shifting cultivation (a common practice prior to the conflict), and increased the focus on keeping small livestock such as chickens. These changes in production went hand in hand with changed eating habits, with far less meat and milk being consumed, and a greater dietary reliance developing upon cereals, legumes and pulses. Participants also explained that the need to supplement meagre food provisions led to the adoption of quicker maturing crop varieties. Because of the smaller land sizes, less labour was needed to meet cultivation requirements, so households began to diversify their livelihoods by engaging in petty trade. This took advantage of the greater trading opportunities that were available in the camps where populations clustered together more tightly for reasons of security. Changing dietary habits and exposure to 
alternative foodstuffs also led to changing cultural tastes and preferences, along with new market demands, which further stimulated the cultivation of non-traditional crops and prompted households to learn new skills, such as the extraction and packaging of fruit juices.

Whilst conflict is often considered to break the social fabric of a society by weakening trust within social networks, these results show that social capital may also be increased in displaced populations. Within camps sharing and cooperation between households was greatly enhanced. In addition, new social practices developed such as engaging in informal village meetings; a practice which participants reported was retained after displaced populations returned home. Such reconfiguration of social networks and the emergence of new spaces for change are clear examples of how innovation systems were changing in line with AIS thinking (Leeuwis and Aarts, 2011). Positive interactions in the social networks within camps also led to the formation of groups and associations, and participants noted in particular that women's groups were formed; a reflection of the changing gender roles that conflict impacts on household composition had triggered. Women were widely considered to be more empowered than their male counterparts following the conflict, with much greater participation in commercial activities and the public sphere after the conflict than before. The new social networks that formed in camps were complimented by the expansion of communication technology across South Sudan, with participants indicating that use of mobile phones and FM radio stations was on the rise. This facilitated contact between those who had stayed behind, gone to different areas, or were returning home at different times, enhancing abilities to spread innovations geographically, and coordinate new opportunities for trade and development.

\section{DISCUSSION}

The results presented here have provided evidence that agricultural innovation does not cease when lives and livelihoods are uprooted following conflict and displacement. To the contrary, the findings suggest that processes of conflict and displacement can lead to greater levels of agricultural innovation, as those affected undergo new experiences and have no choice but to respond to changing production conditions, incentives and opportunities. This reflects reports that long-term refugee camps can have a 'catalytic impact on local trade, business, transport and agricultural production' (Crisp, 2003: 9). The idea that conflicts and displacement can open 
opportunities is recognised in the wider literature, for example in psychology (opportunities for shaping lives and identities (Ager and Ager, 2010)) or disasters studies (opportunities for institutional reform (Birkmann et al., 2010)). However, it has gained less attention in studies concerned with agricultural development.

Research participants attributed the uptake of agricultural innovation to the necessity of adapting their production practices to smaller land areas, to the relaxation of traditionally restrictive gender roles, to the acquisition of new tastes and preferences resulting from exposure to different cultural experiences, and to the greater accessibility of information and innovation support. Indeed, the locations to which farmers were displaced were characterised by closer proximity of dwellings and enhanced access to support services such as education and NGOs. Although some of what was reported by research participants reflects some aspects of traditional Diffusion of Innovations models (for example that individuals are more likely to accept information about innovations coming from individuals that they trust), participants largely attributed greater rates of innovation to the greater levels of access to institutions and social networks which prevailed within refugee camps and IDP settlements. In other words, the locations to which research participants were displaced featured better-functioning agricultural innovation systems. How to tap into and actively build on the innovation systems that have developed as a result of displacement is an important question for agencies wishing to enhance agricultural recovery in such circumstances.

The results highlight the importance of institutional access as well as social capital for enabling agricultural innovation in line with the AIS concept. Within the literature there is disagreement over the impacts of conflict on social capital, with some perspectives suggesting that violent conflict destroys the social fabric of society, but others finding that social capital recovers quickly following conflict (De Luca and Verpoorten, 2015). Whilst the experience of conflict may result in social alienation, participants attest that they experienced altruism and solidarity within their communities in the camps where they were based, The findings here suggest that displacement may have temporarily increased social capital by facilitating greater levels of communication within social networks, and fostering market participation and openness to new cultural experiences, which to some extent was maintained after the return from displacement. Social networks not only increased in size in terms of their membership numbers because of the closer proximity of camp inhabitants, but 
also grew in terms of their geographical coverage, through the ties of camp inhabitants to others that were displaced elsewhere, or remained at home.

Whilst there was a decline in access both to institutions supporting agricultural innovation and to social networks when displaced persons returned to their former more widely-spaced patterns of traditional habitation, respondents felt they could put their experiences to use. Formerly displaced smallholder farmers now carried with them and embodied new values, habits and expectations regarding their livelihoods and agricultural activities, in addition to the new skills and knowledge linkages they acquired during displacement. Agricultural development organisations working in post-conflict settings may thus find it fruitful not only to concentrate on supporting the spread of the specific new innovations that have been adopted throughout the conflict and displacement process, but also to find ways to build on the agricultural innovation systems that have been formed during displacement.

Following resettlement to original locations, it is important to find ways to enhance and sustain communications within the social networks that formed during times spent in refugee and IDP camps. Opportunities identified by respondents in this study could be replicated elsewhere, and could include exploiting mobile phone technology which is increasingly available throughout Africa (Kayisire and Wei, 2016), using media channels such as agriculture-focussed roving radio programmes, and supporting opportunities for innovators to come together again through events, exchange visits or for participatory action research activities. The support for women's groups is a concrete example in our results that shows how post-conflict rehabilitation programmes working with an AIS approach can strengthen the institutions that were built during displacement.

The findings of this research are particularly striking when one considers the conditions that displaced Sudanese refugees faced in camps where they were offered asylum. Authors considering conditions in the camps in Uganda, CAR and Kenya have attested that they were located in particularly environmentally harsh and economically deprived locations (Vemuru et al., 2016). The fact that high levels of agricultural innovation nonetheless resulted in these situations attests to the role of social factors as key determinants of innovation, even when economic and environmental determinants are weak. The fact that participants indicated that the clear majority of support for agricultural innovation came through informal networks 
made up of households, friends, neighbours and family members further highlights the autonomous potential of reconfigured social and environmental spaces resulting from displacement to contribute to processes of innovation.

In South Sudan, as elsewhere, protracted displacement has become the norm, meaning that refugees and IDPs may spend up to decades in their new locations, with large numbers potentially never returning home. Moreover, protracted conflicts may not end definitively, and physical assets may be lost yet again as violence once more flares up. Considering this, mechanisms for supporting those that have been (or are likely to be) displaced should focus also on providing assets that are transferable and transportable, such as skills and knowledge. These results show that there is potential to tap into and actively build on innovation systems developed during displacement. Social capital is recognised as key to post-conflict recovery, not only because it increases civil society participation, but also because it offers conflict survivors the psychological support they desperately need following the trauma they have undergone (De Luca and Verpoorten, 2015).

Further, in situations of protracted conflict and displacement, rigid -often Western- perspectives that strictly separate war and peace, (seeing war as a temporary aberration from a norm of peace), may be at odds with the lived experiences of populations affected by these protracted crises, where enduring war may itself have become a norm (Richards, 2005). Whilst the former viewpoint may see in war an inevitable dislocation of innovation and developmental processes, the latter is more likely to focus on attempting to achieve development goals and innovation despite conflict and displacement. Given the statistics on prolonged displacement -with those who have been displaced for more than five years with no immediate prospect of returning home rising quickly since 2016 (UNHCR, 2018)- it is essential that policies are implemented which better support agricultural development for displaced populations. The evidence presented here and empirical reports from elsewhere (Airriess, 2005; Hellin et al., 2018) demonstrate that agricultural development and innovation can be achieved and supported under conditions of conflict and following displacement, and suggest that greater recognition of this potential should promote new modes of development support for affected populations, enhancing their abilities to develop and participate in new and evolving Agricultural Innovation Systems that have been stimulated by changing circumstances. While many nations continue to place major restrictions on the productive activities in which refugees are legally 
permitted to engage (Clements and Shoffner, T. Zamore, 2016), our study shows the need for rethinking such policies through an AIS lens and better supporting the potential for agricultural development amongst refugees and IDPs, which may even provide the foundations for greater stability in the future. 


\section{CONCLUSION}

This article shows how conflict-induced displacement of farming populations in South Sudan influences processes of agricultural innovation. Given the growing number of displaced populations, it is crucial to better understand how agricultural livelihoods of rural populations can best be supported during and after displacement. This support, we argue, should work from an understanding of the dynamic nature of agricultural innovation and the informal, autonomous and networked modes of agricultural support and learning as expressed in an Agricultural Innovation Systems approach.

Our results show that agricultural innovation intensified during displacement where exposure to new production contexts and cultural preferences both necessitated and incentivised changes to agricultural livelihood activities. Displaced households were able to access better agricultural information and support, learn new skills, and importantly engage in new modes of organisation and social networks. Although the intensity of innovation had dropped again when they returned to their widelydispersed dwelling patterns, respondents were able to use their experience to enrich their livelihoods.

We highlight the embodied, continued institutional changes, including changed gender roles, continuation of women's groups, and new values and expectations regarding agricultural practices and wider livelihood activities. Whilst our respondents had returned to South Sudan, some members of families and friends remained settled in the countries they had been displaced to. Informal networks of friends and family therefore continued across borders between returnees and nonreturnees, further facilitating knowledge exchange and expanding access to diverse resources and markets.

The informal sharing of advice between displaced households resulting in changes to agricultural livelihood practices shows the autonomous innovation capacity of displaced population. Where legal rights of refugee populations to engage in economically and agriculturally productive activities allow it, supporting knowledge exchange and experimentation could further facilitate agricultural innovation. In particular, tools that enable individuals to enhance their long-term levels of social and human capital may contribute to lasting agricultural innovation capacity, especially against a backdrop of protracted violent conflict where physical assets are at continued risk of being ceased or destroyed. 
We suggest that programmes aiming at supporting agricultural innovation among populations returning from displacement take an Agricultural Innovation Systems approach that recognises -and actively builds on- the experiences and the dynamic networks and institutions built during displacement. Further research is needed, both among displaced and returned populations, to understand temporal and geographical dynamics of agricultural innovation.

\section{Acknowledgements}

We thank the Commonwealth Scholarship Commission UK for funding a doctoral position at the University of Reading. This article draws on findings from this study. We also thank the Windle Trust International and the Ministry of Agriculture of the Republic of South Sudan for providing support in terms of facilitation and logistics during the field work. We also thank all respondents who offered their time to participate in this household survey or focus groups.

\section{REFERENCES}

Agarwal, B. (1983) 'Diffusion Of Rural Innovations - Some Analytical Issues And The Case Of Wood-Burning Stoves', World Development 11(4): 359-76.

Ager, W. and A. Ager (2010) 'The Psychology of Enforced Mobility', in S. Carr (ed.) The Psychology of Global Mobility, pp. 151-70. Springer New York.

Agwu, A.E., M.U. Dimelu, and M.C. Madukwe (2008) 'Innovation System Approach to Agricultural Development: Policy Implications for Agricultural Extension Delivery in Nigeria', African Journal of Biotechnology 7(11): 1604-11.

Airriess, C.A. (2005) 'Governmentality and Power in Politically Contested Space: Refugee Farming in Hong Kong's New Territories, 1945-1970', Journal of Historical Geography 31(4): 763-83.

Birkmann, J. et al. (2010) 'Extreme Events and Disasters: A Window of Opportunity for Change? Analysis of Organizational, Institutional and Political Changes, Formal and Informal Responses after Mega-Disasters', Natural Hazards 55(3): $637-55$.

Bruch, C. and C. Muffett (2016) Governance, Natural Resources and Post-Conflict 
Peacebuilding. New York: Routledge.

Buhaug, H. and J.K. Rød (2006) 'Local Determinants of African Civil Wars, 19702001', Political Geography 25(3): 315-35.

Clements, K.T. and L. Shoffner, T. Zamore (2016) 'Uganda's Approach to Refugee Self -Reliance', Forced Migration Review 52: 49-51.

Cramer, C. and P. Richards (2011) 'Violence and War in Agrarian Perspective', Journal of Agrarian Change 11(3): 277-97.

Crisp, J. (2003) No Solution in Sight: The Problem of Protracted Refugee Situations in Africa, UNHCR Working Paper.

Daoust, G. (2015) Sudan and South Sudan.

Engel, P. and W. van den Bor (1995) 'Agricultural Education from a Knowledge Systems Perspective: From Teaching to Facilitating Joint Inquiry and Learning', European Journal of Agricultural Education and Extension 1(4): 1-23.

Ferris, E. (2012) 'Internal Displacement in Africa: An Overview of Trends and Opportunities'. Ethiopian Community Development Council Annual Conference, London (2-4 May 2012).

German, L., J. Mowo, and M. Kingamkono (2006) 'A Methodology for Tracking the "Fate" of Technological Interventions in Agriculture', Agriculture and Human Values 23(3): 353-69.

Hall, A., W. Janssen, E. Pehu, and R. Rajalahti (2007) Enhancing Agricultural Innovation: How to Go beyond the Strengthening of Research Systems. Washington, DC: The World Bank.

Hellin, J., B.D. Ratner, R. Meinzen-Dick, and S. Lopez-Ridaura (2018) 'Increasing Social-Ecological Resilience within Small-Scale Agriculture in ConflictAffected Guatemala', Ecology and Society 23(3): art5.

Hirblinger, A.T. (2015) 'Land, Political Subjectivity and Conflict in Post-CPA Southern Sudan', Journal of Eastern African Studies 9(4): 704-22.

IDMC and Norwegian Refugee Council (2018) Global Report on Internal 
Displacement. Geneva.

Kayisire, D. and J. Wei (2016) 'ICT Adoption and Usage in Africa: Towards an Efficiency Assessment', Information Technology for Development 22(4): 63053.

Klerkx, L., B. Van Mierlo, and C. Leeuwis (2012) 'Evolution of Systems Approaches to Agricultural Innovation: Concepts, Analysis and Interventions', in I.

Darnhofer et al. (eds) Farming Systems Research into the 21st Century: The New Dynamic, pp. 457-83. Dordrecht: Springer.

Van Leeuwen, M., M. Van de Kerkhof, and Y. Van Leynseele (2018) 'Transforming Land Governance and Strengthening the State in South Sudan', African Affairs 117(467): 286-309.

Leeuwis, C. and N. Aarts (2011) 'Rethinking Communication in Innovation Processes: Creating Space for Change in Complex Systems', The Journal of Agricultural Education and Extension 17(1): 21-36.

De Luca, G. and M. Verpoorten (2015) 'Civil War, Social Capital and Resilience in Uganda', Oxford Economic Papers 67(3): 661-86.

Mekonnen, D.K., D.J. Spielman, E.G. Fonsah, and J.H. Dorfman (2015) 'Innovation Systems and Technical Efficiency in Developing-Country Agriculture', Agricultural Economics 46(5): 689-702.

Moris, J. (1991) Extension Alternatives in Tropical Africa. Overseas Development Institute, London.

Muscat, R.J. (2005) 'Reviving Agriculture in the Aftermath of Violent Conflict: A Review of Experience', Journal of Peacebuilding \& Development Vol. 2(No. 2): $77-92$.

Østby, G., R. Nordås, and J.K. Rød (2009) 'Regional Inequalities and Civil Conflict in Sub-Saharan Africa', International Studies Quarterly 53(2): 301-24.

Prager, K. and H. Posthumus (2010) 'Socio-Economic Factors Influencing Farmers' Adoption of Soil Conservation Practices in Europe', in T.L. Napier (ed.) Human Dimensions of Soil and Water Conservation. New york: Nova Science 
Publishers.

Richards, P. (2005) No Peace, No War : An Anthropology of Contemporary Armed Conflicts. Ohio: Ohio University Press.

Roberts, N. (1989) 'The World Bank and the Training and Visit System in East Africa', in N. Roberts (ed.) Agricultural Extension in Africa. Washington DC: World Bank.

Rogers, E.M. (2003) Diffusion of Innovations. Fifth Edition. Free Press, New York, London, Toronto, Sydney.

Roling, N. and P.G.. Engel (1991) 'The Development of the Concept of Agricultural Knowledge Infoormation Systems (AKIS): Implications for Extension', in W.M. Rivera and D.. Gustafson (eds) Agricultural Extension: Worldwide Institutional Evolution and Forces for Change. Elsevier Ltd.

Röling, N. and J. Pretty (1997) ‘Extension's Role in Sustainable Agricultural Development', in B. Swanson et al. (eds) Improving Agricultural Extension. A Reference Manual. Rome: Food and Agriculture Organization of the United Nations.

Röling, N.G., D. Hounkonnou, S.K. Offei, R. Tossou, and A. Van Huis (2004) 'Linking Science and Farmers' Innovative Capacity: Diagnostic Studies from Ghana and Benin', NJAS - Wageningen Journal of Life Sciences 52(3-4): 21135.

Sperling, L. (2002) 'Beyond Seeds and Tools: Effective Support to Farmers in Emergencies', Disasters (United Kingdom) 26(4): 26(4):283-287.

Spielman, D.J. and R. Birner (2008) How Innovative Is Your Agriculture? Using Benchmarks to Strengthen National Agricultural Innovations Systems. Washington DC: World Bank.

Straus, S. (2012) 'Wars Do End! Changing Patterns of Political Violence in SubSaharan Africa', African Affairs 111(443): 179-201.

Tran, T.A. (2015) 'Post-Disaster Housing Reconstruction as a Significant Opportunity to Building Disaster Resilience: A Case in Vietnam', Natural Hazards 79(1): 
$61-79$

UNDP (2015) United Nations Development Programme - South Sudan Annual Report.

UNHCR (2017) Statistical Yearbook 2016, UNHCR Statistics Technical Series.

UNHCR (2018) Global trends. Forced displacement in 2017.

Vemuru, V. et al. (2016) An Assessment of Uganda's Progressive Approach to Refugee Management. Washington DC: World Bank Group.

Vervisch, T.G. a, K. Vlassenroot, and J. Braeckman (2013) 'Livelihoods, Power, and Food Insecurity: Adaptation of Social Capital Portfolios in Protracted CrisesCase Study Burundi', Disasters 37(2): 267-92.

World Bank (2012) Agricultural Innovation Systems: An Investment Sourcebook. Washington DC. 
Table 1. List of post-displacement agricultural innovations in South Sudan

\begin{tabular}{|c|c|c|c|}
\hline $\begin{array}{l}\text { Agricultural } \\
\text { Practices } \\
\text { traditional to } \\
\text { South Sudan (SS) }\end{array}$ & $\begin{array}{l}\text { Agricultural } \\
\text { Innovations }\end{array}$ & Sources & $\begin{array}{l}\text { Actors that supported } \\
\text { the innovations during } \\
\text { displacement }\end{array}$ \\
\hline $\begin{array}{l}\text { Long maturing } \\
\text { sorghum varieties }\end{array}$ & $\begin{array}{l}\text { Medium maturing } \\
\text { varieties (Akurchot, } \\
\text { Graham Hamam, } \\
\text { Sekedo) }\end{array}$ & $\begin{array}{l}\text { Ethiopia, } \\
\text { Sudan, and } \\
\text { Uganda } \\
\text { respectively }\end{array}$ & $\begin{array}{l}\text { Individuals, traders and } \\
\text { CARE respectively }\end{array}$ \\
\hline $\begin{array}{l}\text { Lowland/irrigated } \\
\text { rice varieties }\end{array}$ & Upland rice varieties & $\begin{array}{l}\text { Uganda and } \\
\text { DRC }\end{array}$ & $\begin{array}{l}\text { Individual farmers and } \\
\text { AAHI }\end{array}$ \\
\hline $\begin{array}{l}\text { Subsistence } \\
\text { vegetable } \\
\text { production with } \\
\text { traditional varieties }\end{array}$ & $\begin{array}{l}\text { Widespread } \\
\text { adoption of } \\
\text { commercial } \\
\text { vegetable } \\
\text { production using } \\
\text { 'exotic' varieties } \\
\text { (for example } \\
\text { eggplant and } \\
\text { spineless okra) }\end{array}$ & $\begin{array}{l}\text { Kenya and } \\
\text { Uganda }\end{array}$ & $\begin{array}{l}\text { CARE Uganda, Goal, } \\
\text { UNICEF }\end{array}$ \\
\hline $\begin{array}{l}\text { Karambwa, } \\
\text { Iganyako, Worube, } \\
\text { and Baraja } \\
\text { traditional cassava } \\
\text { varieties in Central } \\
\text { Equatoria state } \\
\text { (usually bitter and } \\
\text { low yielding, } \\
\text { taking around two } \\
\text { years to mature) }\end{array}$ & $\begin{array}{l}\text { High-yielding, short } \\
\text { maturing varieties } \\
\text { (including Nase 1, } \\
\text { Nase } 2 \text { and Nase 3, } \\
\text { TME14, TME24, } \\
\text { TME5 and } \\
\text { TME204) }\end{array}$ & Uganda & $\begin{array}{l}\text { Mainly NGOs (NPA, } \\
\text { CRS, AAHI and } \\
\text { UNICEF) as part of } \\
\text { livelihood support during } \\
\text { the conflict period }\end{array}$ \\
\hline
\end{tabular}




\begin{tabular}{|c|c|c|c|}
\hline $\begin{array}{l}\text { Avocado not } \\
\text { traditional to SS }\end{array}$ & $\begin{array}{l}\text { Widespread avocado } \\
\text { production }\end{array}$ & $\begin{array}{l}\text { Mainly from } \\
\text { Uganda and } \\
\text { DRC }\end{array}$ & Individuals \\
\hline $\begin{array}{l}\text { Fruits (mangoes } \\
\text { consumed fresh } \\
\text { with large amounts } \\
\text { often wasted during } \\
\text { seasonal production } \\
\text { peaks) }\end{array}$ & $\begin{array}{l}\text { Solar fruit drying, } \\
\text { especially for } \\
\text { mangoes }\end{array}$ & $\begin{array}{l}\text { Uganda and } \\
\text { DRC }\end{array}$ & A church group in Yei \\
\hline $\begin{array}{l}\text { Traditional free- } \\
\text { range poultry } \\
\text { production largely } \\
\text { for subsistence }\end{array}$ & $\begin{array}{l}\text { Commercial poultry } \\
\text { production and sale } \\
\text { largely involving } \\
\text { women }\end{array}$ & $\begin{array}{l}\text { Uganda and } \\
\text { Kenya }\end{array}$ & AAHI \\
\hline $\begin{array}{l}\text { Honey production } \\
\text { from wild bees }\end{array}$ & $\begin{array}{l}\text { Bee keeping using } \\
\text { the Kenya Top Bar } \\
\text { and Langstroth hives }\end{array}$ & Kenya & $\begin{array}{l}\text { Individual farmers, NPA, } \\
\text { AAHI }\end{array}$ \\
\hline $\begin{array}{l}\text { Fish farming not } \\
\text { traditional to } \\
\text { Central Equatoria } \\
\text { state }\end{array}$ & $\begin{array}{l}\text { Growing fish in } \\
\text { water bodies closely } \\
\text { integrated with } \\
\text { household farm }\end{array}$ & $\begin{array}{l}\text { Uganda, } \\
\text { South Sudan }\end{array}$ & $\begin{array}{l}\text { Training by ACORD } \\
\text { whilst in refugee camps } \\
\text { in Uganda, AAHI and } \\
\text { NPA also provided } \\
\text { training to farmers in } \\
\text { South Sudan }\end{array}$ \\
\hline $\begin{array}{l}\text { Use of hand held } \\
\text { farm implements }\end{array}$ & $\begin{array}{l}\text { Animal drawn } \\
\text { implements such as } \\
\text { ox-plough gaining } \\
\text { popularity }\end{array}$ & $\begin{array}{l}\text { Uganda, } \\
\text { DRC, } \\
\text { Kenya and } \\
\text { Ethiopia }\end{array}$ & $\begin{array}{l}\text { Individual farmers with } \\
\text { support from } \\
\text { development NGOs such } \\
\text { as Care and AAHI }\end{array}$ \\
\hline $\begin{array}{l}\text { Manual grinding of } \\
\text { cereals by women } \\
\text { and girls }\end{array}$ & $\begin{array}{l}\text { Use of inexpensive } \\
\text { diesel-powered mills }\end{array}$ & $\begin{array}{l}\text { Uganda and } \\
\text { DRC }\end{array}$ & $\begin{array}{l}\text { Individuals, mainly } \\
\text { adopted by women's } \\
\text { organisations }\end{array}$ \\
\hline
\end{tabular}




\begin{tabular}{|l|l|l|l|}
\hline $\begin{array}{l}\text { Traditional } \\
\text { extension methods } \\
\text { (for example } \\
\text { extension workers } \\
\text { visit farms) }\end{array}$ & $\begin{array}{l}\text { Introduction of } \\
\text { Farmer Field } \\
\text { Schools (FFS) } \\
\text { extension method }\end{array}$ & $\begin{array}{l}\text { Kenya and } \\
\text { Uganda }\end{array}$ & $\begin{array}{l}\text { Farmers willingness to } \\
\text { continue attending } \\
\text { attributed to good } \\
\text { experiences with FFS in } \\
\text { Kenya and Uganda. } \\
\text { Promoted in SS by NPA } \\
\text { and in DRC by AAHI }\end{array}$ \\
$\begin{array}{l}\text { In pastoralist } \\
\text { communities men } \\
\text { responsible for } \\
\text { herding, whilst } \\
\text { women engaged in } \\
\text { household roles }\end{array}$ & $\begin{array}{l}\text { shifted to arable } \\
\text { farming and women } \\
\text { increasingly } \\
\text { involved in livestock } \\
\text { trading }\end{array}$ & DRC & $\begin{array}{l}\text { Individual farmers, } \\
\text { AAHI }\end{array}$ \\
\hline
\end{tabular}

AAHI - Action Africa Help International

CRS - Catholic Relief Services

DRC - Democratic Republic of Congo

NPA - Norwegian People's Aid

Source: this study

Table 2. Frequency of using sources of information regarding agricultural innovations reported by 13 focus groups

\begin{tabular}{lr|r|r|r|r} 
& N & Min* & Max* & Mean & $\begin{array}{c}\text { Std. } \\
\text { Deviation }\end{array}$ \\
\hline $\begin{array}{l}\text { Relatives and } \\
\text { friends }\end{array}$ & 13 & 4 & 5 & 4.4 & 0.48 \\
\hline Media & 13 & 2 & 4 & 2.8 & 0.68 \\
\hline NGOs & 13 & 2 & 3 & 2.6 & 0.50 \\
\hline Other farmers & 13 & 2 & 4 & 2.5 & 0.66 \\
\hline Government & 13 & 1 & 2 & 1.3 & 0.48 \\
\hline
\end{tabular}

* answers were given on a scale of 1 (almost never) to 5 (very frequent)

Source: this study 
Table 3. Mean access to support services in displaced and non-displaced locations

\begin{tabular}{|l|l|l|l|l|}
\hline & $\begin{array}{l}\text { Access in } \\
\text { refugee } \\
\text { camps }\end{array}$ & $\begin{array}{l}\text { Access in } \\
\text { internally } \\
\text { displaced } \\
\text { locations }\end{array}$ & $\begin{array}{l}\text { Access for } \\
\text { those that } \\
\text { never left }\end{array}$ & Average \\
\hline Education & 3.67 & 3.31 & 1.85 & 2.94 \\
\hline Health & 3.38 & 3.00 & 1.92 & 2.77 \\
\hline Technology & 2.54 & 2.00 & 1.31 & 1.95 \\
\hline Markets & 3.00 & 2.69 & 2.00 & 2.56 \\
\hline NGOs & 3.31 & 3.23 & 1.00 & 2.51 \\
\hline Extension & 2.62 & 1.46 & 1.00 & 1.69 \\
\hline Credit & 1.38 & 1.23 & 1.00 & 2.31 \\
\hline Relief food & 2.23 & 2.38 & 1.31 & \\
\hline Average & $2.77 *$ & & & \\
\hline
\end{tabular}

Note: average scores (range 1 to 5) from 13 focus group discussions

* Differences significant at 0.05 level (pair-wise Mann-Whitney test)

Source: this study 